\title{
Effect Of Competitive Advantage As A Mediator Variable Of Entrepreneurship Orientation To Marketing Performance
}

\author{
Achmad Zaini 1, Djumilah Hadiwidjojo2, Fatchur Rohman 2, Ghozali Maskie 2 \\ ${ }^{I}$ ( Doctoral Program of Management Science / Faculty of Economics and Business of Brawijaya University / \\ Malang East Java Indonesia ) \\ ${ }_{2}^{2}$ Department of Management / Faculty of Economics and Business of Brawijaya University / Malang East Java \\ Indonesia )
}

\begin{abstract}
This research is aimed to determine direct and indirect effects of entrepreneurship orientation on marketing performance via competitive advantage. This research also examines the role of learning orientation in this relationship. The location of this research in Small Medium Enterprises (SMEs) export in Great Malang Territory Indonesia. Result show that there were effect of entrepreneurship orientation on the performance of marketing. The role of competitive advantage as mediators of marketing performance was very important, but it was not followed by learning orientation, because there was no significant affect between this variable on marketing performance.
\end{abstract}

Keywords: effect, competitive advantage, mediator variable, entrepreneurship orientation and marketing performance

\section{Introduction}

The world economy is now in crisis and all countries experience economic slowdown. Because of that every country is required to establish policies that can improve the durability of its economy in order not to be dragged into this global crisis. Indonesia is trying to improve the performance of the economy through the formal sector which is supported by large corporations as well as state and private parties, and informal sector which is widely supported by Small and Medium Enterprises ( SMEs ). It is believed that the SME is able to improve national economy and to overcome the economic problems in the country due to its enormous potential [1,2]. SMEs marketing performance can be achieved if the company has a high competitive advantage. Marketing performance of a company is reflected in the work results of various functional management interacting with each other proportionally to perform its functions well [3,4,5]. Marketing performance can also be achieved properly if companies implement entrepreneurship orientation which is a mechanism of selection that causes learning and exploratory behavior and decision making in product innovation [6,7]. Entrepreneurship orientation aims to create value for customers [8], which is very important to make them satisfied with the company performance. Entrepreneurship orientation should be supported with a high learning desire to continue to improve the quality of performance.

\section{Previous Research}

\section{Review Of Literature}

Wang [9] found that learning orientation can mediate the relationship between entrepreneurship orientation and marketing performance, and learning orientation should be done to maximize the impact of entrepreneurship orientation on marketing performance. Another research conducted by Lin et al [10] from Taiwan revealed no significant effect of entrepreneurship orientation on learning orientation also there was no significant effect of entrepreneurship orientation on innovativeness via learning orientation. Supranoto [11] found that there were three factors that could significantly affect the competitive advantage, namely: market orientation, innovation, and entrepreneurship orientation . In addition, this study also found a link between competitive advantage and marketing performance. Subsequent studies by Rhee [12] showed that the market orientation and entrepreneurship orientation significantly affected learning orientation . These research findings imply that entrepreneurship orientation and market orientation should emphasize on learning orientation in order to improve the ability of innovation (innovativeness ) and to improve marketing performance ultimately.

\section{Review of Theory Orientation Entrepreneurship}

Entrepreneurship is a creative and innovative capabilities that form the basis and resources to look for opportunities to success [13]. According to Kottler [14], entrepreneurship marketing is an integrated concept in an era of change. Entrepreneurship marketing itself is defined by Morris and Lewis [15] as an activity to identify proactive efforts to achieve and sustain customer through innovative approach to risk management, resource 
effectiveness, and the development of values. Entrepreneurship element that is widely known is freedom and autonomy [16,17], proactive and innovation [18,19], and courage to take risks [20,21,22].

\section{Learning Orientation}

Learning orientation is a process by which individuals try to gain new knowledge and insights that can develop and improve the behavior and actions [23]. Furthermore, [1,2]. Garvin [24] defines organizational learning as a process in which company learn to have expertisment in creating, learning and transferring knowledge and attitudes. Three values are often used as indicators of organizational learning orientation are : commitment to learning, openness of thought, and a shared vision $[25,26,27,28,29]$. These values are the core components showing the learning orientation construct

\section{Competitive Advantage}

Competitive advantage can be obtained if the company can create value or benefit higher than cost. Consumers actually purchase the value or benefits of the product or service. If consumers get high value or benefits with low price than offered by competitors, the company already has a competitive advantage. Competitive advantage can also be derived from offering lower prices than what is offered by competitors for equivalent benefits or unique benefits [30]. Some common indicators used to measure the competitive advantage include: the uniqueness of the product, products quality, and competitive prices. The uniqueness of the product is the combination of the company artistic value with the customer's tastes. The product quality is the quality of design , materials and technology of the products, while the competitive price is the company's ability to adjust the price to market prices [30]

\subsubsection{Marketing Performance}

Marketing performance is a concept to measure the market performance of a product. Every company is interested to know the market performance of its products in order to identify its business success in the competition. Marketing performance is a construct or a common factor used to measure the impact of a corporate strategy. Sitorus [31] stated that the quality of marketing performance that is supported by an understanding to the consumers and new product advantages are the key to increase the success in creation of superior value for consumers. The creation of superior value for consumers is a stepping stone for a company to improve marketing performance. More simple and practical concept is also described by Ferdinand [5] who states that a good marketing performance is expressed in three major scales namely: customer growth, sales growth, and the market share, which ultimately leads to profitability.

\section{Research Concept}

Research Framework Concept

The application of entrepreneurship orientation can improve marketing performance [14]. Similarly, the orientation of the learning can also effect on marketing performance [32] and also on competitive advantage. Once companies achieve competitive advantage it can affect performance [11]. The conceptual framework begins with the relationship of entrepreneurship orientation with learning orientation. Slater and Narver [33] state that the encouragement of entrepreneurship culture becomes the foundation for organizational learning which enables the company to achieve a higher level of marketing performance and better customer value .

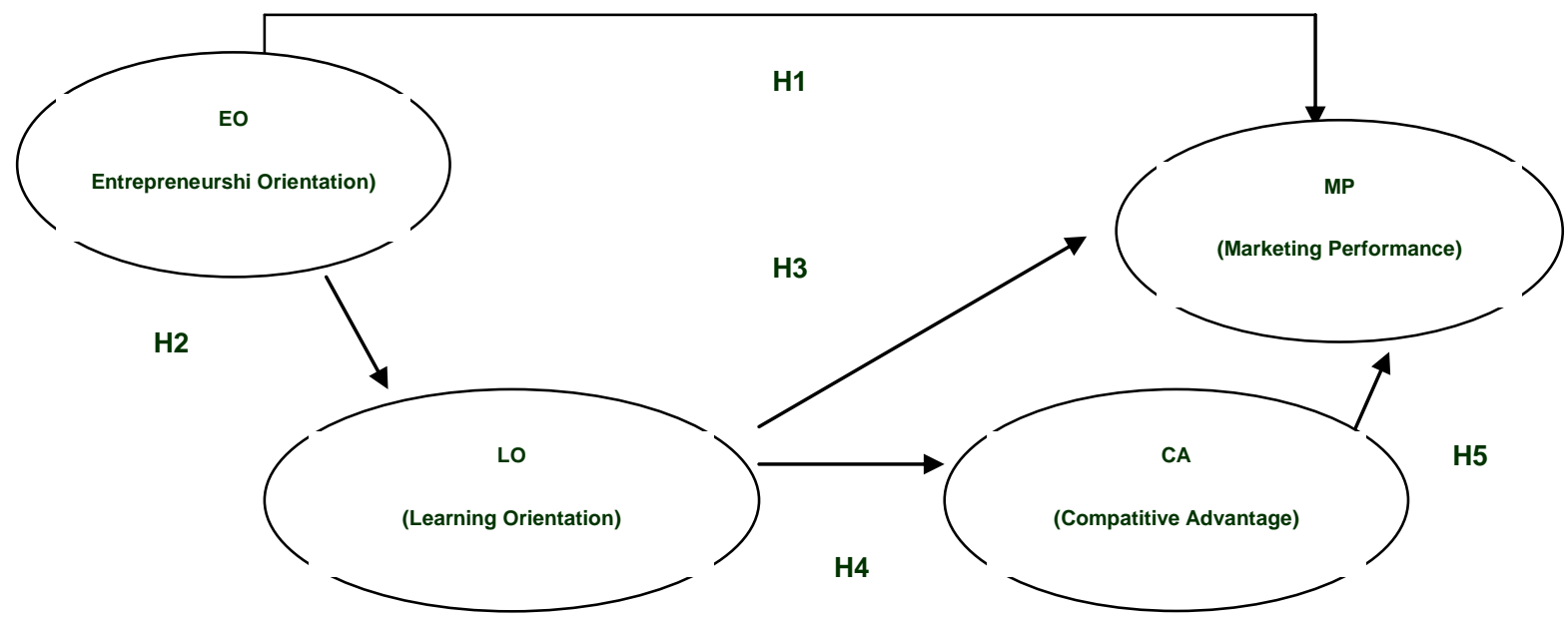

Figure 1 : Research Framework Concept 
Research Hypothesis

Hypothesis 1(H1): Entrepreneurship orientation has positive significant effect on the marketing performance

Hypothesis

2(H2) : Entrepreneurship orientation has positive significant effect on the learning orientation Hypothesis Hypothesis 3(H3) : Orientation learning has positive significant effect on the marketing performance Hypothesis 4(H4) : Orientation learning has positive significant effect on competitive advantage 5(H5) : Competitive advantage has positive significant effect on marketing performance

\subsection{Inner Model ( Structural Model )}

\section{Research Result}

Inner assessment model can be seen from the $\mathrm{R}$ - square value (Table 1), and can be measured as Goodness of Fit Model . Model Goodness of Fit value was obtained by calculating the Q-Square predictive relevance $\left(\mathrm{Q}^{2}\right)$. The result is a value of $\mathrm{Q}^{2}=1-(1-0,362)(1-0,321)(1-0,366)=0,567$. Thus the model can explain the relationship between marketing performance (MP) and competitive advantage (CA), learning orientation (LO) and entrepreneurship orientation (EO) as big as $56.7 \%$, and the remaining of $43.3 \%$ is explained by other variables outside the model and error .

Table $1: \mathrm{R}$-square values per variable

\begin{tabular}{|c|c|}
\hline Variable & R-square \\
\hline EO & 0,000 \\
\hline LO & 0.362 \\
\hline CA & 0.321 \\
\hline MP & 0.366 \\
\hline
\end{tabular}

\subsection{Hypothesis Testing}

Hypothesis testing is indicated by the parameter of path coefficient and the level of significance.

Table 2 : Direct Influence Coefficients and Hypothesis Testing

\begin{tabular}{|c|c|c|r|c|l|c|}
\hline Hypothesis & Correlation & $\begin{array}{c}\text { Path } \\
\text { Coefficients }\end{array}$ & P-Value & \multicolumn{1}{|c|}{ t -Statistic } & \multicolumn{2}{|c|}{ Remark } \\
\hline H1 & EO $\rightarrow$ MP & 0.238 & 0.044 & 2.661 & Sig & accepted \\
\hline H2 & EO $\rightarrow$ LO & 0.612 & 0.000 & 10.839 & Sig & accepted \\
\hline H3 & LO $\rightarrow$ MP & 0.178 & 0.060 & 1.558 & Non Sig & $\begin{array}{c}\text { Not } \\
\text { accepted }\end{array}$ \\
\hline H4 & LO $\rightarrow$ CA & 0.705 & 0.004 & 10.125 & Sig & accepted \\
\hline H5 & CA $\rightarrow$ MP & 0.176 & 0.000 & 1.714 & Sig & accepted \\
\hline
\end{tabular}

Description : $\mathrm{t}$-stat $=$ significant at $\alpha=0.05$ level

Sources : PLS Processed in 2013

Further it needed to be revealed the indirect relationship between the variables with a possible role of mediating variable.

Table 3 Path Coefficient of Indirect Influence

\begin{tabular}{|c|c|c|c|c|c|c|}
\hline \multicolumn{4}{|c|}{ Variable } & \multirow[t]{2}{*}{$\begin{array}{c}\text { Path } \\
\text { Coefficient }\end{array}$} & \multirow[t]{2}{*}{ Remark } & \multirow[t]{2}{*}{ Mediation Type } \\
\hline Exogen & & tion & Endogen & & & \\
\hline $\begin{array}{l}\text { Entrepreneurship } \\
\text { Orientation(EO) }\end{array}$ & $\begin{array}{l}\text { Learning } \\
\text { Orientation } \\
\text { (LO) }\end{array}$ & $\begin{array}{c}\text { Marketing } \\
\text { Performance } \\
\text { (MP) }\end{array}$ & & 0.109 & Not Sig & Non Mediation \\
\hline $\begin{array}{l}\text { Entrepreneurship } \\
\text { Orientation(EO) }\end{array}$ & $\begin{array}{c}\text { Learning } \\
\text { Orientation } \\
\text { (LO) }\end{array}$ & $\begin{array}{c}\text { Competitive } \\
\text { Advantage (CA) }\end{array}$ & $\begin{array}{c}\text { Marketing } \\
\text { Performance } \\
\text { (MP) }\end{array}$ & 0.076 & Sig & $\begin{array}{l}\text { Complete } \\
\text { Mediation }\end{array}$ \\
\hline
\end{tabular}




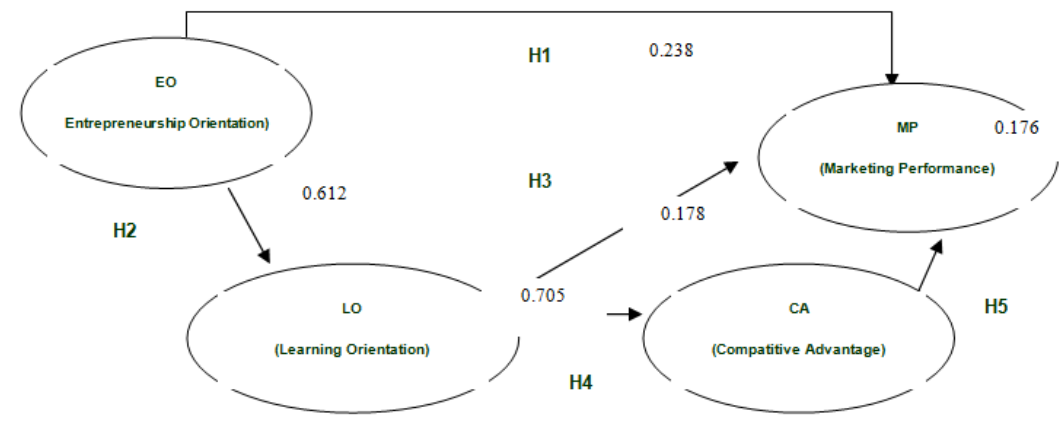

Figure 2 : Research Result

\section{Discussion}

\section{The effect of entrepreneurship orientation on marketing performance}

Hypothesis 1 (H1), shows positive significant effect of entrepreneurship orientation on marketing performance. Results suggest that the higher entrepreneurship activities of SMEs the higher marketing performance can be achieved. This finding is consistent with research conducted by Hazmi [34] who found that there was a positive significant influence of entrepreneurship orientation on marketing performance of company. These findings are also in line with Weerawardena's [13], stating that companies which conduct entrepreneurship activities will encourage higher performance. Similarly Doukakis [35]also state that high entrepreneurship activity is the key to success of performance because the main function of entrepreneurship orientation is to get optimal performance. Significant positive influence of entrepreneurship orientation on marketing performance suggests that SMEs export in Malang needs intensive conduct of entrepreneurship activities to achieve a high marketing performance. Entrepreneurship is realized by the courage of SMEs export in facing barriers, obstacles, and challenges as well as risks, and this become the key factors driving their success . Entrepreneurs who dare to take the risk and to see uncertainty as a challenge and dare to come in unknown market as well as accept failure gracefully would be a successful entrepreneur [36]. SME entrepreneurs who have an high entrepreneurship spirit tend to see the chances of success not the failure notice and assume failure as a learning process. Howerver the findings of this study differ from the results of Wang research [9] where the relationship between entrepreneurship orientation and marketing performance was significant and positive only if mediated by learning orientation .

\subsection{The effect of entrepreneurship orientation on learning orientation}

Results of hypothesis 2 testing (H2) prove that there is a positive significant effect of entrepreneurship orientation on learning orientation. The results show that SMEs entrepreneur have to dare to make their own decisions (autonomy), dare to take risks and be proactive to take opportunities. They are also encouraged to have a high commitment to learning, be open-minded and broad-minded. The results of this study are consistent with the findings of the research conducted by Hazmi [34] (2004) and Wang [9]. In these research, similar findings indicate that there is a positive significant relationship between entrepreneurship orientation and learning orientation. These findings reinforce theory of Zimmerer and Scarborough [37], which states that a person who has an entrepreneurship orientation has the ability to think freely. With the ability to think freely, a person will always try to think independently and not bound by the beliefs and values shared by the surrounding community. The findings of this study are not consistent with the study conducted by Lin et al [10],showing that entrepreneurship orientation did not significantly influence learning orientation

\subsection{The effect of learning orientation on marketing performance.}

Results of hypothesis 3 testing (H3) shows that there is no evidence of a positive significant effect of learning orientation on SME export marketing performance. The findings of research among SMEs export in Malang is consistent with the findings of research conducted by Vijande [38] also Suliyanto and Rahab [39] which claim that learning orientation does not significantly influence the marketing performance. These findings suggest that the activity of SMEs to improve organizational values in creating and utilizing knowledge has no effect at all on the marketing performance. Likewise, company intention and sincerity in running principles, organizational values and vision of SMEs to open sources of information as much as possible have no effect on marketing performance. These findings are very interesting because a lot of experts state that learning orientation has positive significant effect on business performance and one of them is Baker \& Sinkula [40]. The findings of this study are not consistent with the results of Martinette and Leeson [41] and Farrell [42] who show the significant relationship between learning orientation and marketing performance. Another study 
conducted by Jimenez and Navarro [43] also found a significant relationship between learning orientation and marketing performance.

\subsection{The effect of learning orientation on competitive advantage.}

Testing results of hypothesis $4(\mathrm{H} 4)$ prove that there is a positive significant effect of learning orientation towards SMEs export competitive advantage. These results are consistent with the findings of Sinkula Baker[40] which states that the high level of the learning process will be increasingly important in creating a sustainable competitive advantage in the company. Findings of this study also support Martinette and Leeson's research [41] which showed a significant relationship between learning orientation and competitive advantage. The research results can be concluded that in order to have a good competitive advantage of SMEs should encourage climate and good learning culture. This conclusion is in line with the idea of Barney [44] which states that an organization will have a sustainable competitive advantage if it has the resources or expertise that can give superior value to customers. Superior resources can only be gained by continuing updating knowledge and skills through the learning process. This finding is slightly different from that evidenced by Suliyanto [45] which showed that the orientation of learning has positive significant effect on competitive advantage only if it through innovation ,especially technological innovation

\subsection{Effect of competitive advantage on marketing performance.}

Testing of hypothesis 5 (H5) prove that there is a positive significant influence of the competitive advantage on marketing performance. The findings of this study are consistent with the results of study by Supranoto [11] and Kusumo [46] who found that competitive advantage significantly affect the performance of marketing. These findings also support Droge and Vickery [47] who claim that the competitive advantage of the company will ultimately affect the company's market performance as measured through customer growth. Competitive advantage is a SMEs position of superiority in the market through distinctive competencies and strategic assets of the company. Marketing performance is a measure of achievement gained from the activities of SMEs in overall marketing process. Marketing performance can be seen from the accomplishments such as: sales growth, growth in number of consumers, market share growth and an increase in profits. The findings of this study are not consistent with the findings of research conducted by Prakosa [48] which shows that marketing performance significantly influence to competitive advantage. Similarly, these findings differ with the theory proposed by Slater and Narver [40] which states that the effective corporate marketing performance is a configuration of practical management that provides facilities for the development of knowledge as a basis of competitive advantage.

\section{Conclusions}

\section{Conclusions And Suggestions}

From the study, it can be concluded thet : (1) Learning orientation has no direct influence on the performance of marketing ; (2) Competitive advantage to be a good mediator of learning orientation to performance marketing as a complete mediation ; (3) Competitive advantage needed to improve marketing performance, both directly and indirectly as a mediator of learning orientation.

\section{Suggestions}

Based on the research results can be suggested that : (1) A certain form of learning that can improve competitive advantage; (2) Preliminary research needs to be done to follow up on the results of this study as a recommendation to SME exports in Malang; (3) Implementation of further research can be conducted with different subjects or broader scope.

\section{References}

[1]. Klobor, P.L, Ini dia lima koperasi indonesia berkelas dunia, JaringNews.com, 13 JUli 2012

[2]. Suarja, W.A.R, Kebijakan pemberdayaan UKM dan koperasi guna, menggerakkan ekonomi rakyat dan menanggulangi kemiskinan, (LPPM. IPB, Bogor, 2007)

[3]. Zhou, K.Z., Yim, C.K.B. and Tse, D.K., "The effects of strategic orientations on technology - and market-based breakthrough innovations", Journal of Marketing, 69, 2005,42-60.

[4]. Voss, G. B and Voss, Z. G., Strategic orientation and firm performance in an artistic environment, Journal of Marketing, 64, 2000

[5]. Ferdinand, A., Sustainable competitive advantage : sebuah eksplorasi model konseptual. (Fakultas Ekonomi Universitas Diponegoro. Semarang , 2003)

[6]. Lumpkin, G.T. and Dess, GG, Clarifying the entrepreneurship orientation construct and linking it performance. Academy of Management Review. 21(1), 1996, 135-172.

[7]. Miller D, The correlates of entrepreneurship in three types of firm, Management Science, 29, ,1983. 770-791.

[8]. Sciascia, S., Naldi, L., Hunter, E., Market orientation as determinant of entrepreneurship: an empirical investigation on SMEs. New England Journal of Entrepreneurship 2, 2006, 21-38.

[9]. Wang, C.L., Entrepreneurship orientation, learning orientation, and firm performance. Entrepreneurship Theory \& Practice 32 (4), $2008,635-657$. 
[10]. Lin, C.H., Peng, C.H., Kao, D.T., The innovativeness effect of market orientation and learning orientation on business performance, International Journal of Manpower, 29(8), 2008, 752-772

[11]. Supranoto,M., Strategi menciptakan keunggulan bersaing produk melalui orientasi pasar, inovasi, dan orientasi kewirausahaan dalam rangka meningkatkan kinerja pemasaran (studi empiris pada industri pakaian jadi skala kecil dan menengah di kota Semarang ), Theses ,Diponegoro University 2009

[12]. Rhee,J.; Park, T.; Lee, D.H., Drivers of innovativeness and performance for innovative SMEs in South Korea: Mediation of learning orientation ,Journal of Technovation ,30,2010,65-75

[13]. Weerawardena, J., Exploring the role of market learning capability in competitive strategy. European Journal of Marketing..37, 2003,407-429.

[14]. Kotler, P , 2001, Marketing management, (Prentice-Hall, Upper Saddle, 2001)

[15]. Morris, H., Lewis, P.S, The determinants of entrepreneurship activity, implication for marketing. European Journal of Marketing, 29(7), 2002.

[16]. Kuratko, D. F., \& Hodgetts, R. M., Entrepreneurship: a contemporary approach, Third Edition ed. ( Fort Worth: Dryden Press, 2001)

[17]. Stevenson, H.H. \& Jarillo, J.C.,A paradigm of entrepreneurship: entrepreneurship management. Strategic Management Journal, 11, 1990, 17-27.

[18]. Pitt, L. F., Berthon, P. R., \& Morris, M. H, Entrepreneurship pricing: The Cinderella of marketing strategy. Journal of Management Decision, 35(5), 1997,344-350.

[19]. Yeoh, P. and Jeong, I., Contingency relationships between entrepreneurship, export channel structure, and environment, European Journal of Marketing, 29(8), 1995, 95-115.

[20]. Hornsby, J. S., Naffziger, D. W., Kuratko, D. F., \& Montagno, R. V.,An interactive model of the corporate entrepreneurship Process. Theory and Practice, $17,1993,29-37$.

[21]. Luchsinger, V., \& Bagby, D. R., Entrepreneurship and intrapreneurship: Behaviors, comparisons, and contrasts. S.A.M. Advanced Management Journal, 1987, 10-13.

[22]. Sathe, V.,Fostering entrepreneurship in the large diversified firm. Organizational Dynamics, 18(2), 1989, $20-32$.

[23]. Stata, R., Organizational learning - The key to management innovation, Sloan Management Review, 30(3), 1989, 45-62.

[24]. Garvin, D. A, Building a learning organization, Harvard Bussiness Review, 1993,. 78-91.

[25]. Day, G.S. , Market Driven Strategy, Processes for Creating Value.(New York: The Free Press. 1990)

[26]. Day, G.S., "Continuous learning about markets," California Management Review, 36, 1994a,. 9-31.

[27]. Senge, P. M, The leader's new work: building learning organizations, Sloan Management Review, 1990a,7-23.

[28]. Senge, P. M, The Fifth Discipline.( New York: Doubleday, 1990b)

[29]. Tobin, D. R.,Re-educating the corporation: foundations for the learning organization. (Essex Junction, VT: Oliver Wight Publications, 1993)

[30]. Porter, M. E., Keunggulan bersaing : menciptakan dan mempertahankan kinerja unggul, (Erlangga, Jakarta, 1993)

[31]. Sitorus F.H.,M., Analisis pengaruh kompetensi pengetahuan pasar terhadap kinerja pemasaran melalui keunggulan produk baru (studi empiris pada industri mebel di Jepara), Jurnal Sains Pemasaran Indonesia, 3(1), 2004.

[32]. Baker, W. E., and Sinkula,J.M. ,The Synergistic effect of market oriented and learning organization on organization perfomance. Journal of The Academy Marketing Science. 1999, 411-427.

[33]. Slater, S.F and Narver, J., Market orientation and the learning organization, Journal of Marketing, 59(3), 1995. 63-74.

[34]. Hazmi, Analisis pengaruh sikap kewirausahaan, orientasi pasar dan pembelajaran organisasi terhadap kinerja, Theses ,Diponegoro University, 2004

[35]. Doukakis, I.P., The Role of employee development in customer relations : The case of UK retail banks, Corporate Communications : An International Journal, 79(2), 2002, 62-76

[36]. Looy, V. B., Debackere, K. \& Andries, P. , Policies to stimulate regional innovation capabilities via university-industry collaboration: an analysis and an assessment. R\&D Management, 33 (2),2003, 209-229.

[37]. Zimmerer, T.W. dan Scarborough, N.M., Essentials of entrepreneurship and small business ( Management, Prentice-Hall,Inc., 2003)

[38]. Vijande, M.L.S; Perez, M.J.S; Gonzalez, L.I.A; Casielles, R.V.,Organizational learning and market orientation: interface and effects on performance, Journal of Industrial Marketing Management, 34, 2005,187- 202

[39]. Suliyanto and Rahab, The role of market orientation and learning orientation in improving innovativeness and performance of small and medium enterprises, Asian Social Science 8(1), 2012,134-145

[40]. Baker, W. E. and Sinkula, J. M.,Learning orientation, market orientation, and innovation: integrating and extending models of organizational performance. Journal of Market-Focused Management, 4(4), 1999. 295-308.

[41]. Martinette,L.A. and Leeson ,A.O.,The relationship between learning orientation and business performance and the moderating effect of competitive advantage: a service organization perspective , Journal of Service Science, 5(1), 2012, 43-58

[42]. Farrel, M.A.,Developing a market-oriented learning organisation, Australian Journal of Managemet, 25(2), 2000, 201-223

[43]. Jiménez, D.J.; Navarro, J.G.C , The performance effect of organizational learning and market orientation, Journal of Industrial Marketing Management,36 ,2007, 694-708

[44]. Barney, J.,Firm resources and sustained competitive advantage, Journal of Management, 17 (1),1991,99-120.

[45]. Suliyanto, The effect of orientation learning on competitive advantage through innovation: study on small and medium enterprises, Business and Management Review, 1(7), 2011,28 - 36

[46]. Kusumo, A.R.W., Analisis faktor-faktor yang mempengaruhi inovasi produk untuk meningkatkan keunggulan bersaing dan kinerja pemasaran (studi pada industri batik skala besar dan sedang di kota dan kabupaten Pekalongan), Theses ,Diponegoro University , 2006

[47]. Droge, C. dan Vickery,S., Source and outcomes of competitive advantage : an explanatory study in the furniture industri. Journal of Decision Sciences,25(5) 1994, $669-689$.

[48]. Prakosa, B., Pengaruh orientasi pasar, inovasi dan orientasi pembelajaran terhadap kinerja perusahaan untuk mencapai keunggulan bersaing (studi empiris pada industri manufaktur di Semarang), Jurnal Studi Manajemen dan Organisasi, 2(1), 2005. 